\title{
Architecture Planning Information Manufacture Systems Using Enterprise Architecture Planning At PT. Tin Tin
}

\author{
P Sidiq $^{1}$, D D Bhakti \\ (purnomosidiq@institutpendidikan.ac.id)
}

Department of Information System Institute Pendidikan Indonesia (IPI) Garut, Jawa Barat, Indonesia ${ }^{1,2}$

\begin{abstract}
PT Tin Tin is a company engaged in the manufacture of soy sauce sweet, salty and balsamic vinegar, which has been established since 1970 and started developing since the year 2000, with the segment of middle class consumers. Focuses on the market share of the housewives, restaurants and traders of the wheel circumference, with the type of variant shaped packaging bottle, sachet or refill, with types of brands of soy sauce that is adapted to segment the buyer and region marketing, including brand Kuntji and Papaya.On the condition of the existing design will be SI/TI at this time not integrated in the information technology utilization and better and of course SI/TI is very necessary in the development of the information system in accordance with the needs of key business processes. With the Architecture of the Enterprise (EA) is one way of realizing the description of the system enterprise manufacturing in a logical manner, intact and complete, with a results-oriented business architecture, information architecture, application architecture and technology architecture, with method Architecture Enterprise Planning (EAP) approach framework Zachman. Of plan benefits as well as advantages of the implementation of development planning the new architecture, will provide a huge benefit to the main business process in improving the efficiency and effectiveness of the work, in improving the quality and quantity of production to produce a very high profit, and can improve the productivity of human resources in the work. With planning Architecture Enterprise Planning (EAP) described in the modeling business according to the organization identified 25 business function 7 business processes, schemes of information technology are connected, the architecture of the data on the candidate data entities 41 entities, the data base tersentralisasikan accessed by all organizational units in PT Tin Tin, application architecture identification on candidate 41 applications, technology architecture 30 network infrastructure technology supporting a business that is connected as a whole.
\end{abstract}

Keywords: Information Systems Architecture, EAP, Information Systems, Manufacturing

\section{Introduction}

\subsection{Background}

Developments in current information technology is growing so fast, so the need in the process so quick and advanced. Information technology is jteknologi that can process business processes, data processing, manipulation, save, change and save data with a variety of flatpon with accurate, relevant and quick in making decisions especially the development of the industry manufakture is now included in the business process at PT. Tin Tin. PT. Tin Tin is a company manufakture manufacture of soy sauce sweet, salty and balsamic vinegar, which has been established since 1970, focusing on the market share of the housewives, restaurants and traders of the wheel circumference, with the type of variant shaped packaging bottle, sachet or refill, including brand Kuntji and Papaya.

In support of current business processes, PT. Tin Tin has an information system that is still simple is conventional so that an error occurs in the data processing, so that the information is processed slowly and efficiency, so it needs to be made system apps that are 
new and can help in the activities of the production of soy sauce up to a factory manufakture sauce that is good.[1]

In proposing a framework to manage the planning of information systems through analysis of application portfolio for current, which is necessary for the future . In the enterprise architecture planning analysis of the application portfolio is used to summarize a review of the development application for the implementation of the architecture of the organization [2]. Enterprise architecture is a collection of principles methods, and a model that is plausible which is used to design and realize an organizational structure of the enterprise, business processes, information systems and infrastructure[2].

Enterprise Architecture Planning EAP [2]. EAP is a method used to build an information architecture [3]. Enterprise Architecture Planning is a method of approach to planning data quality that is oriented on the needs of the business as well as how the implementation of the architecture is done in such a way in an effort to support the rotation of the wheel business and the achievement of the contents of the information system and the organization [2]. This research proposes a model of development planning or development of integrated information system as a strategy of development of information systems and information technology to PT. Tin Tin with the needs of the business. The Model of this planning methodology Enterprise Architecture Planning (EAP) with the Zachman Framework. In such a case the addition is more focused on planning the architecture of information on the company, so as to produce a strategic planning of information systems a good.

\subsection{Identification Of Problems}

1. The architecture of the Information System that will later be translated into data architecture, application architecture and technology architecture;

2. Implementation plan/ migration in the application architecture-the architecture, in the information system of the enterprise PT. TIN TIN.

\subsection{The Purpose Of The Research}

1. Plan an architectural model of information system with the approach of the method of enterprise architecture planning according to the needs of the business process conducted by PT. Tin Tin this time, so it can be applied to the information system enterprise manufacturing PT. Tin Tin the results of which can support and support the business processes of the organization running;

2. Connect all of the overall system, so that information systems that are running manual into a system that is connected with the well ; and

3. Give an advantage of the results of the implementation architecture to be made, to the process of strategic business information system PT. Tin Tin so as to give added value, ease, efficient and effective in running the business process of the organization by increasing the company's manufacturing ketchup competitiveness.

\section{The Study Of Theory}

\subsection{Architecture}

Architecture comes from the Greek language that defines the discipline construction and the design of the building, which didalammnya is as the art and technique of designing and building, the Practice of the architecture used to fulfill both practical and expressive of the people civilized, would thus covers, as well as a description of the architecture is a formal description of a system, organized in a way to support a reasoning about the nature of the structural of a system, this mendefisikan block buildings and the components that make up the 
overall system, and provide a plan of the product obtained and the system developed, which work together to implement a system as a whole [4].

\subsection{Zachman Framework}

Zachman Framework or ZF is a scheme or framework to perform the classification of organizing the artifacts of the enterprise and scheme/framework that can be used in the enterprise architecture as a tool to help the thinking/solving at once understand the various issues and problems that are very complex/enterprise in developing a strategy for a better, effective and efficient in a dynamic model/framework that didirancang to attempt to accommodate the problems in the running business processes [3].

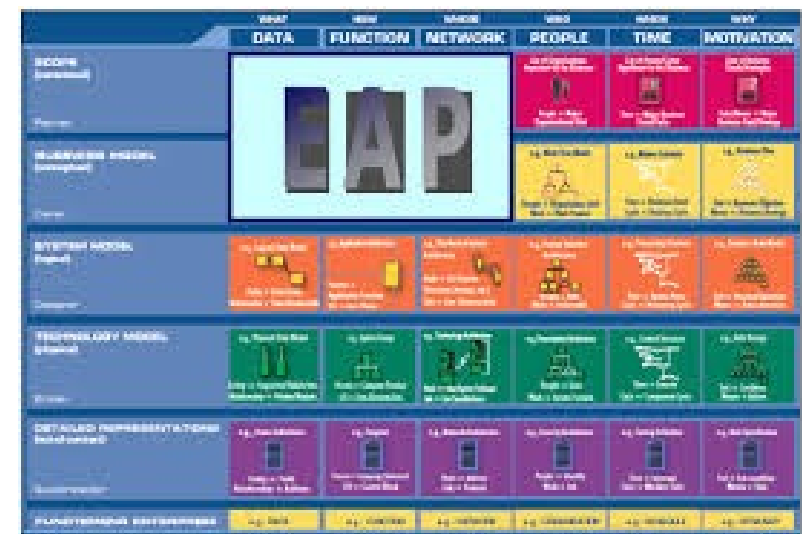

Figure. 1. Using the EAP in the Zachman Framework (Zachman)

\subsection{Enterprise Architecture Planning (EAP)}

Enterprise Architecture Planning hereinafter referred to as EAP, is a method used to build an information architecture. Enterprise Architecture Planning, or EAP, is a method of approach to planning data quality that is oriented on the needs of the business as well as how the implementation of the architecture is done in such a way in an effort to support the rotation of the wheel business and the achievement of the contents of the information system and the organization [5].

\subsection{Portfolio Application}

In the manufacture of the Architecture of the application form Application Portfolio that includes standard and guide the procurement and application development required to support the functions of a company [6]

\subsection{Strategic Planning Information}

The main purpose of strategic planning information is prepare a plan for the management of analysis, planning and development of the system is computer based [6].

In the methodology of engineering information, steps can be viewed from two sides, namely data and activity. For planning information strategy on the side of the data, the direction of the review of the strategic is to the needs of the information needed by the enterprise. While on the activity, the direction of the review of strategic is in terms of the utilization of technology to increase the performance of the enterprise [2].

\subsection{Business Process Modeling Notation (BPMN)}

Business Process Modeling Notation is the standard most commonly to diagram and document business processes. BPMN provides a business analysis, the ability to define and 
understand internal procedures and ekstemal business through the diagram of the business process, which will give organizations the ability to communicate these procedures in a standard way [2].

\subsection{Four Stage Life Cycle Business System Planning (BSP)}

Four stage life cycle to find the derivative of the function of the business associated with the products/services provided by the business function proficiency level. Four stage life cycle on the BSP are at the stage of defining the business process.[2].

\section{Method}

In this research, steps of research refers to the methodology of the Enterprise Architecture Planning (EAP)[3].

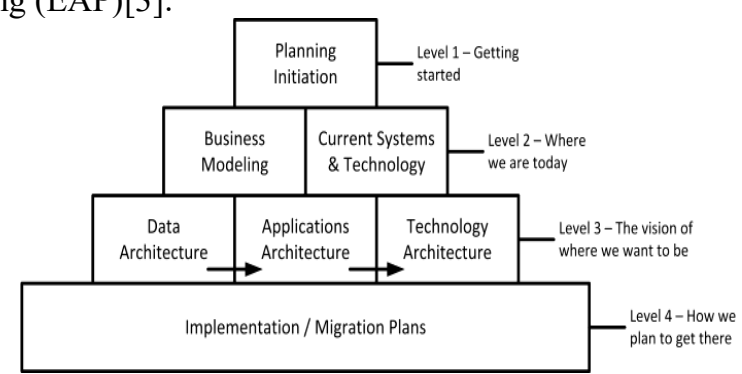

Figure 2. Enterprise Architecture Planning (EAP)

\subsection{The Study Of Literature}

This stage contains a description of the theory findings and research material taken from the reference material which was used as the research.

\subsection{Early Identification}

The stages of identification documents and field observation.

3.3. Information systems planning enterprise architecture, including :

1. Planning Innitiation

a. The vision and Mission of the Architecture of the Information System

b. Scope and Objectives the Manufacture of EAP

2. Business Modeling

a. Documentation Of The Organizational Structure

b. Identification Of Business Functions

c. Documentation Of The Business Model

1). The Model Of Value Chain (Value Chain)

2). Business System Planning (BSP)

3). Four Stage Life Cycle Key Business Functions

d. Relationship of Business Functions and Organizations

3. Systems and Current Technology
a. Catalog The Use Of The Software
b. Catalog The Use Of Hardware
c. Catalog of current Network

4. Findings and Observations

5. Data Architecture

a. The Candidate Data Entities 
b. Identification of Data Entities, Attributes of Entities, Relations Between Entities and Relationships of the Business Function-Data Entity

1). Entity Data

2). The Entity Attribute Data

c. The Relations Between The Entities

d. Relationship of Business Functions with Data Entities

6. Application Architecture

a. Determine The Candidate's Application

b. The Identification Of The Application

c. Portfolio Of Candidate Applications

d. The relationship of the Applications with the Business Function and the Organization

e. Analysis Of The Impact On The Application Now

7. Technology Architecture

a. The identification of the Principle of Technological and Platform

b. The Definition Of The Enterprise Network Conceptual

c. Relationship Technology Platform with Applications and Business Functions

8. Implementation Plan

a. The Sequence Of Application Development

b. Effort estimation, Resource and Schedule Implementation

c. Estimation of the Costs and Benefits of Plan Implementation

d. Determine Success Factors and Recommendations

\section{Results and Discussion}

In explanation of the foregoing has been described by the author that in the planning stages of the enterprise architecture carried out in several phases of activity beginning with the inisisasi planning to the stages of the transition from the current system towards implementation.

\subsection{Planning Innitiation}

This stage aims to make the framework of the workmanship of enterprise architecture Planning, with effective and efficient, so that the activities of architecture planning can be started as soon as possible in the right direction, resolved right on time.

The stages in this activity is an activity within the stages of initiation, among others, are:

1. Determine the scope and purpose of enterprise architecture planning;

2. Formulating the vision and mission; and

3. Adapting a methodology of planning.

\subsection{Business Modeling}

Business modeling aims to identify all the candidate business functions conducted by the unit stackholder so obtained complete information to define the data architecture, application architecture and technology architecture. In this phase is conducted in two stages, namely the stage of documentation of the organizational structure, and identification of business functions [7].

\subsubsection{Model Of The Value Chain (Value Chain)}

In modeling this business, do stage by step is the identification and documenting organizational structure, identifying the main business areas and supporting with using the model of value chain (Value Chain)[2]. 


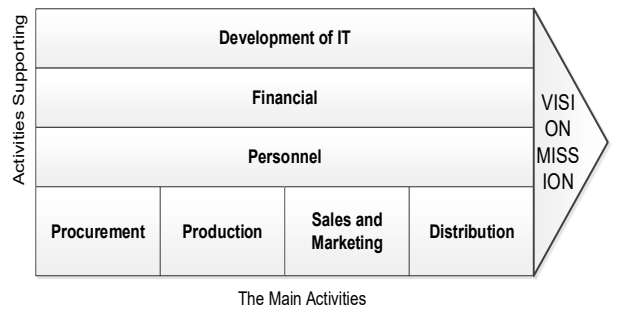

Figure.3 Value Chain Analysis (Value, Chan)

\subsubsection{Business System Planning (BSP)}

Business Model value chain value chan has defined the business function of PT Tin Tin, the next step to determine the decomposition of functions [1]. The decomposition of the business functions is the breakdown of a business function into a business function that more detail or specific (sub-function), by using the approach, method, Tool Four Stage Life Cycle and chart the hierarchy of functions is decomposed into a unitary hierarchy of function into the chart.

\subsection{Systems and Current Technology}

This stage aims to identify all systems and technology platforms that will be used in planning the architecture of entrprise it. The main products that will be produced from this stage is the Information Resource Catalog (IRC), the IRC is a summary or conclusion that there are thoroughly with a not very detailed or standard.

Table 1. Device Software

\begin{tabular}{|c|c|c|}
\hline No & Category Of The Software & Product \\
\hline 1. & Operating system & Ms. Windows XP \\
\hline 2. & RDBMS & SQL Server 2005 \\
\hline 3. & Programming Language & Delphi \\
\hline 4. & Automation of Office & $\begin{array}{l}\text { a. Ms.Office } 2010 \\
\text { b. Adobe Reader }\end{array}$ \\
\hline
\end{tabular}

Table 2. Category of Components the use of Hardware

\begin{tabular}{cll}
\hline No & \multicolumn{1}{c}{ Category Of The Hardware } & \multicolumn{1}{c}{ Product } \\
\hline 1. & Computer & a. Personal Computer (PC) \\
& & b. Ms. Windows XP \\
2. Storage & & a. Flashdisk \\
& & b. Harddisk Internal/external \\
& & c. CD/DVD Room \\
3. & Input Output Device & a. Keyboard \\
& & b. Scanner \\
& & c. Mouse \\
& & d. Monitor \\
& & e. Printer \\
\hline
\end{tabular}


Table 3. Network Devices

\begin{tabular}{cll}
\hline No & Category Of The Network Devices & Product \\
\hline 1. & Networking & a. Intranet \\
& & b. Internet \\
2. Network Device & a. Switch \\
& & b. RJ45 UTP \\
& & c. Modem \\
\hline
\end{tabular}

\subsection{Findings and Observations}

The results of the documentation of the applications and technologies above in addition to can be used as a media analysis to find a number of weaknesses in the system to an existing application, can also be used to provide an overview of the extent to which the organizational unit or the business unit has been using the applications in its business activities.

\subsection{Data Architecture}

Data architecture is a step perform the entity identification of potential data needed to support business processes.

\begin{tabular}{|c|c|}
\hline Candidate Entities & Entity Data \\
\hline 1. Procurement & 01. The Purchase Request \\
\hline & 02. Supplier \\
\hline & 03. Purchase \\
\hline & 04. Warehouse \\
\hline 2. Production & 05. The Production Schedule \\
\hline & 06. Raw Materials \\
\hline & 07. Production \\
\hline & 08. Quality Control \\
\hline & 09. Finished Goods \\
\hline & O10. Maintenance \\
\hline & O 11 . Too1-alatProduksi \\
\hline \multirow[t]{3}{*}{ 3. Sales and Marketing } & 012. Consumers \\
\hline & O 13. The Ordering Of Goods \\
\hline & o14. Sales Order \\
\hline & 015. Promotion \\
\hline \multirow[t]{5}{*}{ 4. Distribution } & 016. Request Delivery \\
\hline & O17. Letters \\
\hline & O18. Sales Invoice \\
\hline & 019. Transport Company \\
\hline & 020. Returns \\
\hline \multirow[t]{6}{*}{ 5. Financial } & 021. Absent \\
\hline & 022. Salary \\
\hline & 023. Cashbon \\
\hline & 024. Rembuise \\
\hline & 025. Payment \\
\hline & 026. Billing Accounts Receivable \\
\hline \multirow{9}{*}{ 6. Personnel } & $\begin{array}{l}\text { 027. Physical Evidence Transaction } \\
\text { 028. Reception Employees }\end{array}$ \\
\hline & 029. Selection of employees \\
\hline & 030. Applicants \\
\hline & 031. Employees \\
\hline & 032. Evaluation \\
\hline & 033. Staffing \\
\hline & 034. Leave \\
\hline & 035. The post \\
\hline & 036. Group \\
\hline \multirow{5}{*}{$\begin{array}{l}\text { 7. The Development } \\
\text { Information Technology }\end{array}$} & 037. IT needs \\
\hline & 038. Hardware \\
\hline & 039. Software \\
\hline & 040. Repair TI \\
\hline & O41. IT procurement \\
\hline
\end{tabular}

Figure 5. The candidate Entities and Data Entities 


\subsection{Architectural Applications}

The purpose of the application architecture is to define some type-the type of the main applications needed for data management and support functions of the business enterprise. The application in the enterprise application architecture is a mechanism to manage an enterprise and related

\subsubsection{Application}

Based on the list of candidates applications can be described into the form of a portfolio of candidate applications.

\begin{tabular}{|l|l||}
\hline \multicolumn{1}{|c|}{ Strategic Application } & \multicolumn{1}{|c|}{ Potential Applications } \\
\hline A. Sistem Informasi Pengadaan & 1. System Manufacturing \\
1. System Of Demand For Goods & 2. Supply Chain Management (SCM) \\
2. System Supplier & \\
3. System Purchase & \\
4. Warehouse Systems & \\
B. System Information Production & \\
1. System Production Schedule & \\
2. System Of Raw Material & \\
3. System Production & \\
4. System Quality Control & \\
5. System Products Goods & \\
6. System Maintenance & \\
7. System Production Tools & \\
C. Information Systems Sales and Marketing & \\
1. System Consumer & \\
2. System Ordering & \\
3. System Sales & \\
4. System Promotion & \\
D. System Information Distribution & \\
1. System Shipping & \\
2. System Letters & \\
3. System Invoice and Sale & \\
4. System Vehicle & \\
5. System Return Goods & \\
\hline & \\
\hline A. System Financial Information & \\
1. System Absent Employees & \\
2. System Employee Salaries & A. System Updates Information Technology \\
3. System Cashbon & \\
4. System Rembuise & \\
5. Payment System & \\
6. System Accounts Receivable & \\
7. System Proof Of Payment & \\
B. System Information Personnel & \\
1. System Recruitment & \\
2. System Selection Employees & \\
3. System Applicants & \\
4. System Employees & \\
5. Evaluation System Emplormation Technology \\
6. Personnel System Emploges \\
7. System Employee Leave & \\
8. System Office Employees & \\
9. Systems Group Employees & \\
\hline & \\
\hline
\end{tabular}

Figure 6. Portfolio Of The Candidate Application

\subsection{Architectural Technology}

The aims of the technology architecture is to define part of the technology-the technology required to provide a form of leisure and scope to an application that functions the data set. The core of the architectural planning of this technology is to obtain an architecture conceptual of an enterprise network. 


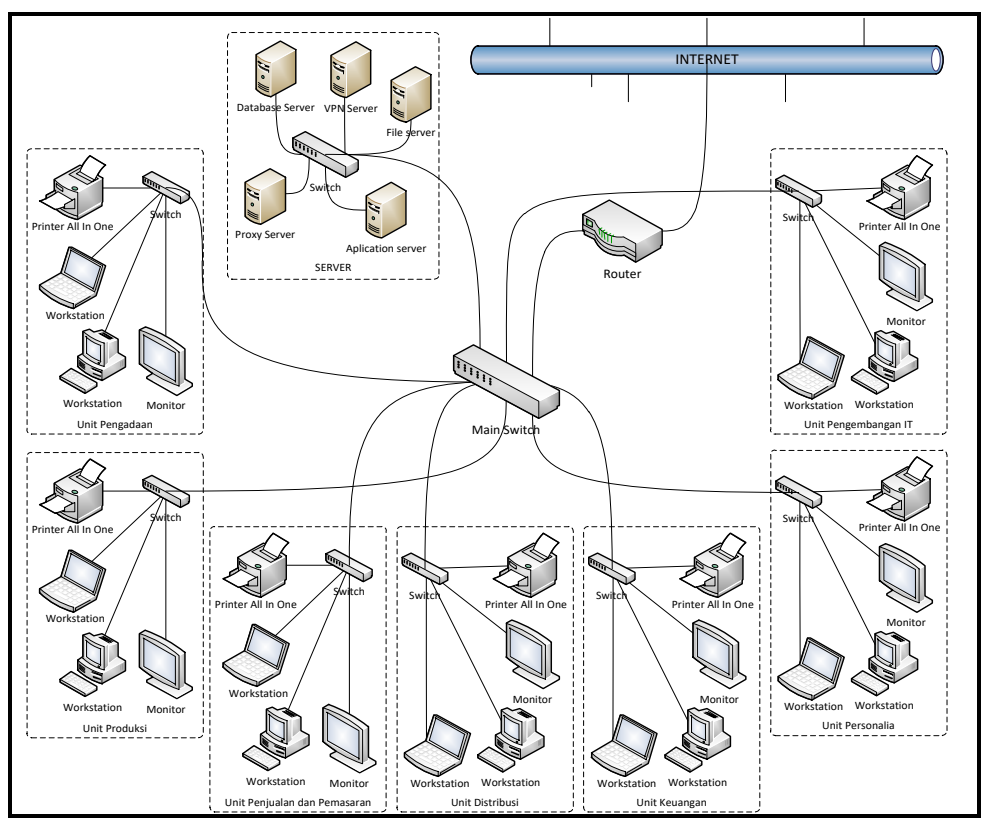

Figure7. Recommendations Enterprise conceptual Network proposed

\subsection{Implementation Plan}

Activity implementation asitektur enterprise, essentially on the application of the implementation is carried out based on the order applications that have been previously generated is based on the application portfolio.

\subsubsection{Estimation of Effort, Resources and Schedule Implementation}

All activities associated with the planning of the development of the new system will be controlled, the scheduling is made based on the needs of the system to be built as well as the sequence of activities pengimplemtasian applications that have been proposed, an overview on the activities of the scheduling implementation on the development of app made. 


\begin{tabular}{|c|c|c|c|}
\hline $\begin{array}{c}\text { Name application } \\
\text { Application }\end{array}$ & $\begin{array}{c}\text { Mounths } \\
\text { Start }\end{array}$ & $\begin{array}{c}\text { Mounths } \\
\text { end }\end{array}$ & $\begin{array}{l}\text { Duration } \\
\text { Mounth }\end{array}$ \\
\hline Total For Project A & 7 & 9 & 2 \\
\hline 1. System Of Demand For Goods & 7 & 8 & 1 \\
\hline 2. System Supplier & 8 & 9 & 1 \\
\hline 3. System Purchase & 8 & 9 & 1 \\
\hline 4. Warehouse Systems & 8 & 9 & 1 \\
\hline Total For Project B & 9 & 13 & 4 \\
\hline 1. System Production Schedule & 9 & 10 & 1 \\
\hline 2. System Of Raw Material & 10 & 11 & 1 \\
\hline 3. System Production & 10 & 12 & 2 \\
\hline 4. System Quality Contro1 & 10 & 11 & 1 \\
\hline 5. System Products Goods & 11 & 12 & 1 \\
\hline 6. System Maintenance & 11 & 12 & 1 \\
\hline 7. System Production Tools & 12 & 13 & 1 \\
\hline Total For Project C & 13 & 15 & 2 \\
\hline 1. System Consumer & 13 & 14 & 1 \\
\hline 2. System Ordering & 13 & 14 & 1 \\
\hline 3. System Sales & 14 & 15 & 1 \\
\hline 4. System Promotion & 14 & 15 & 1 \\
\hline Total For Project D & 15 & 18 & 3 \\
\hline 1. System Shipping & 15 & 17 & 2 \\
\hline 2. System Letters & 16 & 18 & 2 \\
\hline 3. System Invoice and Sale & 16 & 17 & 1 \\
\hline 4. System Vehicle & 17 & 18 & 1 \\
\hline 5. System Return Goods & 17 & 18 & 1 \\
\hline Total For Project E & 18 & 22 & 4 \\
\hline 1. System Absent Employees & 18 & 20 & 2 \\
\hline 2. System Employee Salaries & 19 & 20 & 1 \\
\hline 3. System Cashbon & 19 & 21 & 2 \\
\hline 4. System Rembuise & 20 & 21 & 1 \\
\hline 5. Payment System & 20 & 22 & 2 \\
\hline 6. System Accounts Receivable & 20 & 21 & 1 \\
\hline 7. System Proof Of Payment & $=21$ & 22 & 1 \\
\hline Total For Project F & 22 & 26 & 4 \\
\hline 1. System Recruitment & 22 & 23 & 1 \\
\hline 2. System Selection Employees & 22 & 24 & 2 \\
\hline 3. System Applicants & 22 & 24 & 2 \\
\hline 4. System Employees & 22 & 24 & 2 \\
\hline 5. Evaluation System Employees & 23 & 24 & 1 \\
\hline 6. Personnel System Employees & 23 & 25 & 2 \\
\hline 7. System Employee Leave & 24 & 25 & 1 \\
\hline 8. System Office Employees & 24 & 25 & 1 \\
\hline 9. Systems Group Employees & 25 & 26 & 1 \\
\hline Total For Project G & 26 & 29 & 3 \\
\hline 1. Systems Information Technology & 26 & 27 & 1 \\
\hline 2. System Hardware & 26 & 28 & 2 \\
\hline 3. System Software & 27 & 28 & 1 \\
\hline 4. System Reppair Information Technology & 27 & 29 & 2 \\
\hline 5. System Updates Information Technology & 28 & 29 & 1 \\
\hline Total & 7 & 29 & 22 \\
\hline
\end{tabular}

Figure 8. Estimation of the Application and Plans for Implementation 


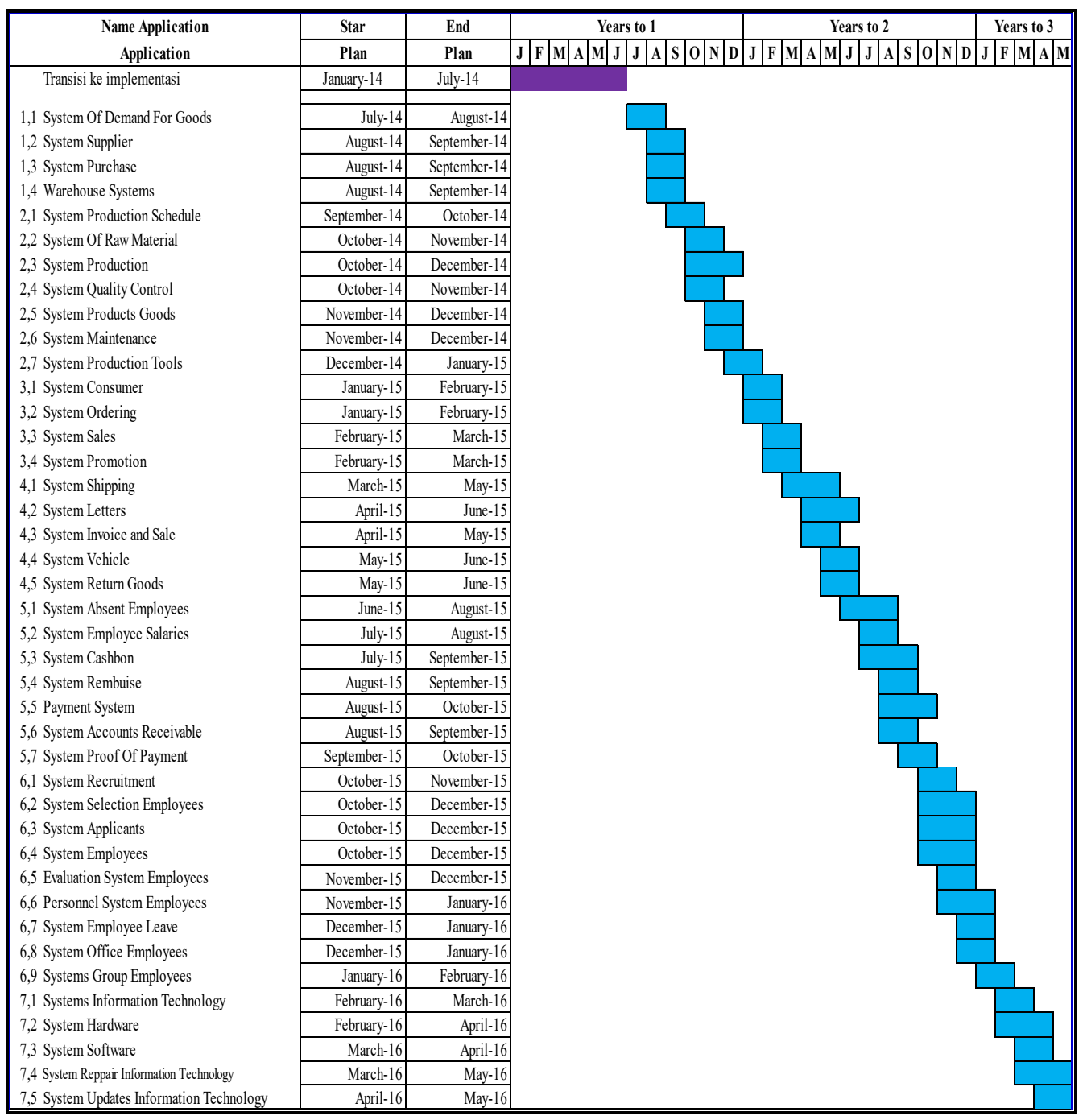

\section{Conclusion}

Figure 9. Roadmap Schedule Implementation Plan

1. Enterprise Architecture planning at PT TIN TIN, is performed with the approach of the method of Enterprise Atchitecture Planning (EAP), with the approach of the framework Zachman

2. The initiation of Planning, doing the planning stages the activity of making architecture, so that activities arranged according to the stages of the EAP methods;

3. Modeling Business, making the business model as appropriate, describe the organization and identify 25 business function 7 business process

4. System and Technology At This Time, do a documentation of a running system, so as to create schemes of information technology are connected; 
5. The architecture Data, identifying the candidate data entities with a total of 41 entities, and have a database that tersentralisasikan and can be accessed by all organizational units in PT TIN TIN;

6. The architecture of the Application, perform the identification on the candidate application with as many as 41 applications and have the application supporting information that is easy to use;

7. Technology architecture, identification of the candidate technology with as many as 30 pieces and has a network infrastructure technology business support a more connected enterprise.

8. The Implementation plan, do the preparation of the implementation of information systems and new technology, so the development of the project implementation can run well in accordance with the plan estimated time and cost and the establishment of the implementation team, which is adjusted with the order of application portfolio.

\section{Acknowledgements}

The author expresses his greatest gratitude to all those who have helped the author in completing this research, assistance in the form of moral and material support. To the Chancellor of the Institute Pendidikan Indonesia of Garut, Dean of the FITS IPI Garut, Chair of the Department of Information System of IPI Garut and colleagues of the Department of Information System at IPI Garut. This research authors hope to be an additional source of information for the advancement of the field of science. Contribute and benefit in the development of information system especially.

\section{References}

[1] K. Surendro, "PEMANFAATAN ENTERPRISE ARCHITECTURE PLANNING UNTUK PERENCANAAN STRATEGIS SISTEM INFORMASI."

[2] "Kridanto Surendro - Pengutipan Google Scholar." [Online]. Available: https://scholar.google.co.id/citations?user=0Vn8MjQAAAAJ\&hl=id. [Accessed: 16Jan-2020].

[3] S. H. Spewak, Enterprise Architecture Planning - Developing a Blueprint for Data, 1st ed. New York, NY, USA: John Wiley \& Sons, Inc, 1993.

[4] "The Definitive Guide to Enterprise Architecture." [Online]. Available: https://www.leanix.net/en/enterprise-architecture?utm_term=enterprise architecture\&utm_source $=$ adwords\&utm_medium $=$ ppc\&utm_campaign $=\mathrm{SG}+\% 7 \mathrm{C}+\mathrm{S}$ 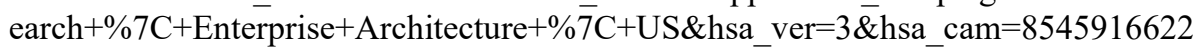 \&hsa_grp $=88083321338 \&$ hsa_acc $=6721847110 \&$ hsa_kw $^{-}$enterprise architecture\&hsa_mt $=$ p\&hsa_net $=$ adwords\&hsa_src $=$ g\&hsa_tgt=kwd10213001\&hsa_ad=405813399760\&gclid=Cj0KCQiAjfvwBRCkARIsAIqSW1Op7Z W6nFQ4okG33P6EltQy_xjJ0luXSBRdrvLBt-tcomra-p1m0yoaAmRZEALw_wcB. [Accessed: 16-Jan-2020].

[5] "BlueDolphin - $\quad$ ValueBlue." [Online]. Available: https://valueblue.com/bluedolphin/?url=https://valueblue.com/bluedolphin/\%3Fhsa_ca $\mathrm{m} \% 3 \mathrm{D} 1675015175$ ?ppc_keyword=architecture framework\&gclid=Cj0KCQiAjfvwBRCkARIsAIqSWIPw0821fqzM_0RYS6XUchYr RdbRJqRJfgqzUtznpToOD6ESBqlFCAkaAhKEEALw_wcB. [Accessed: 16-Jan- 
2020].

[6] E. Setiawati and A. Wibowo, "Perancangan Sistem Informasi Enterprise Architecture di PT. ABC.'

[7] M. N. Imam and S. Handayaningsih, "PEMBUATAN ENTERPRISE ARCHITECTURE PLANNING DENGAN KERANGKA KERJA ZACHMAN DI KOPERASI MAHASISWA UAD YOGYAKARTA,” JSTIE (Jurnal Sarj. Tek. Inform., vol. 2, no. 2, pp. 211-222, 2014, doi: 10.12928/jstie.v2i2.2842. 